\title{
Studies on the Effects of Liming Acidic Soils on Improving Soil Chemical Properties and Yield of Crops: A Review
}

\author{
Mesfin Kuma Megersa \\ Ethiopian Institute of Agricultural Research, Pawe Agricultural Research Center, \\ P.O. Box 25, Addis Ababa, Ethiopia
}

\begin{abstract}
Soil acidity is a major constraint to cropping globally, especially in temperate and tropical regions of the world where high precipitation has been a dominant influence on the pedogenic development of the soil. In agriculture, the limes play a great importance in improving soil acidity and hence favor plant nutrition. The review articles are support the idea that liming ameliorates soil acidity and improve soil chemical properties making it favorable for the crop growth. In an attempt to address soil acidity problems, the application of lime has remarkably improved soil $\mathrm{pH}$ to be optimum desired for crops, increased availability of nutrients and ultimately increased crop yield. Further research would have been required on the same farmer field lime was applied in the next cropping season to observe a significant increase in grain yield. Lime recommendations have to be as specific as possible, taking soils, crops, and climate as well as the financial position of farmers into account. Lime is a recent agriculture input, in Ethiopian context, which worsen the livelihood of smallholder farmers unless credit service or subsidy is facilitated; which also requires an in-depth research.
\end{abstract}

Keywords: Soil acidity, Lime, Plant nutrient

DOI: $10.7176 / \mathrm{JBAH} / 10-15-02$

Publication date:August $31^{\text {st }} 2020$

\section{INTRODUCTION}

Soil acidity is one of the main factors that limit and prevent sustained agricultural productivity and production in many parts of the world (Sumner and Noble, 2003). It is estimated that approximately 50\% of the worlds' arable soils are acidic and may be subjected to the effect of aluminum (Al) toxicity of which the tropics and subtropics account for $60 \%$ of the acid soils in the world (Sumner and Noble, 2003). It is mostly distributed in developing countries, where population growth is fast and demands for food and fiber is increasing. Moreover, the cause of soil acidity is high amount of precipitation that exceeds evapotranspiration, which leaches appreciable amounts of exchangeable bases from the soil surface and continuous application of acid forming chemical fertilizers on highly weathered tropical soils increase soil acidity problem (Nekesa, 2007; Temesgen et al., 2014).

Soil acidity affects the growth of crops because acidic soil contain toxic levels of aluminum and manganese and characterized by deficiency of essential plant nutrients such as $\mathrm{P}, \mathrm{N}, \mathrm{K}, \mathrm{Ca}, \mathrm{Mg}$, and Mo when the soil pH falls below 5.5; and the plant root system is affected by high $\mathrm{Al}$ concentrations because of $\mathrm{Al}$ interferes with the uptake, transport, and utilization of essential plant nutrients such as $\mathrm{P}, \mathrm{K}, \mathrm{Ca}, \mathrm{Mg}$, and water, as well as enzyme activity in the roots (Wang et al., 2006; Lofton et al., 2010; M Abdulaha-Al Baquy et al., 2016). The degree of toxicity depends upon how high the concentration of soluble or exchangeable $\mathrm{Al}^{3+}$ is and how low the $\mathrm{pH}$ is (Crawford et al., 2008). Soil acidity can also reduce the availability of phosphorous by forming insoluble compounds when combined with $\mathrm{Fe}$ and $\mathrm{Al}$ oxide at $\mathrm{pH}<5.0$ (Chude et al., 2004; Kim, 2010). Thus, due to the increased acidity of the soil, inorganic phosphorous applied to the soil becomes fixed or immobilized (Tinker and Nye, 2000). Therefore, acid soils possess toxic concentrations of $\mathrm{Al}^{3+}$ and $\mathrm{Mn}^{2+}$, deficient concentrations of $\mathrm{P}$, and a low availability of bases, which together cause a reduction in crop yield (Schroder et al., 2010). The presence of $\mathrm{Al}$ in plant tissues interferes with $\mathrm{Ca}$ and $\mathrm{Mg}$ uptake from soil, as well as damaging the chloroplast and mitochondrial membrane (Meriño-Gergichevich et al., 2010).

To make soils less acid, it is a common practice to apply a material that contains calcium and/or magnesium oxides or carbonates. Amelioration of acidic soils is beneficial to plant growth because it improves soil $\mathrm{pH}$ and replenishes nutrients (Moon et al., 2014). Moreover, lime applied to acidic soils raises the $\mathrm{pH}$ of soils, resulting in enhanced availability of nutrients, such as $\mathrm{P}, \mathrm{N}, \mathrm{Ca}, \mathrm{Mg}$, Mo etc. and improved crop yields though it reduces exchangeable acidity (Caires et al., 2005; Nekesa, 2007; Kisinyo et al., 2009). Lime has been known as effective ameliorant to reduce soil acidity, decrease exchangeable Al as well as Al saturation (Caires et al., 2008; Achalu et al., 2012; Sadiq and Babagana, 2012). Moreover, the fixed $\mathrm{P}$ would be released for plant uptake after liming, the amount of additional $\mathrm{P}$ needed has to be determined experimentally (Waigwa et al., 2003). This review article is presenting the causes and forms of soil acidity and lime treatment of acidic soil with the objective to review the effect of lime treatment of acid soil on soil chemical property and crop performance. 


\section{LITERATURE REVIEW}

Effect of liming on soil chemical properties

In an attempt to address soil acidity problems, the application of lime has remarkably improved soil $\mathrm{pH}$ to be optimum desired for crops, increased availability of essential nutrients and ultimately increased crop yield. According to Abdissa et al. (2018) showed that the highest increment of pH from 4.83 at the control to 6.05 and reduction of exchangeable $\mathrm{Al}$ from 1.70 to $0.09 \mathrm{cmolc} \cdot \mathrm{kg}^{-1}$ were obtained from combined application of lime at 4 $\mathrm{t} \mathrm{ha}^{-1}$. The most significant decrease in exchangeable acidity $\left(0.17 \mathrm{cmolc} \mathrm{kg}^{-1}\right)$ was observed in soil that was treated with $6 \mathrm{t} \mathrm{ha}^{-1}$ lime applied alone $(93 \%)$ and combined application of lime at $4 \mathrm{t} \mathrm{ha}^{-1}$ with vermicompost at 7.5 tons $\mathrm{ha}^{-1}$ by $(81 \%)$. The highest contents of OM $(4.1 \%)$ and total nitrogen $(0.29 \%)$ were obtained from combined application of lime at 4 tons $\mathrm{CaCO}_{3} \mathrm{ha}^{-1}$ and vermin-compost at 7.5 tons $\mathrm{ha}^{-1}$.

According to Sultana et al. (2009) also observed the application rates of lime levels to soil progressively increased soil $\mathrm{pH}$ and increased availability of $\mathrm{P}, \mathrm{Ca}$ and $\mathrm{Mg}$ in soils. Liming is beneficial for wheat production in the Ranishankail soil series of Dinajpur. The application of lime $2 \mathrm{t} \mathrm{ha}^{-1}$ appears to be optimum for desired soil $\mathrm{pH}$ for wheat $(>\mathrm{pH} 6.0)$, increased availability of essential nutrients and ultimately increased wheat productivity. Application of lime improves soil pH above 5.5 for about four years only (Kisinyo, 2016). Getachew et al. (2017) showed that application of lime rates raised soil $\mathrm{pH}$ close to the optimum $\mathrm{pH}$ requirement of barley; but radically decreased the exchangeable $\mathrm{Al}^{3+}$ to a minimum level of $0.1 \mathrm{cmol} \mathrm{kg}^{-1}$ which enhanced available phosphorus as a result of increased $\mathrm{pH}$ and decreased acidity level.

The Domagoj et al. (2012) studied the significant liming impact on soil chemical properties and maize grain yield. Application of different rates of lime progressively raised soil $\mathrm{pH}$ (5.27 to 8.4). Available phosphorus content was improved 8.6 to $13.1 \mathrm{mg} / 100 \mathrm{~g}$ soil by higher liming rates. Andy and Abdullah (2016) indicated that soil chemical analysis after harvest showed that liming increased soil $\mathrm{pH}$, soil $\mathrm{N}$, organic $\mathrm{C}$, available $\mathrm{P}$, exchangeable of $\mathrm{K}$ and $\mathrm{Mg}$, decreased of $\mathrm{Al}$ exchangeable and $\mathrm{Al}$ saturation compared with no lime plot.

Achalu et al. (2012) reported that applied the different rates of lime and soil $\mathrm{pH}$ were developed to establish optimum lime required to reduce the severity of exchangeable acidity raise the soil $\mathrm{pH}$ under different land use systems. According to Tadesse et al. (2018) revealed that the highest application of $6 \mathrm{tha}^{-1}$ lime rate increased the soil $\mathrm{pH}$ from 5.07 to 5.64 and high significantly reduced the exchangeable acidity from 0.96 to $0.19 \mathrm{cmolc} \mathrm{kg}^{-1}$ and exchangeable $\mathrm{Al}$ from 0.37 to $0.0 \mathrm{cmolc} \mathrm{kg}$. As Adane (2014) study indicated that application of $3.75 \mathrm{t} \mathrm{ha}^{-1} \mathrm{lime}^{-1}$ increased soil $\mathrm{pH}$ from 5.03 to 6.72 and significantly reduced the exchangeable acidity 0.97 to $0.36 \mathrm{mg} \mathrm{kg}^{-1}$. Moreover, liming significantly $(\mathrm{P} \leq 0.05)$ increased Cation Exchange Capacity 19.18 to $33.34 \mathrm{cmol}^{(+)} \mathrm{kg}^{-1}$; available Phosphorus 5.36 to $7.04 \mathrm{mg} \mathrm{kg}^{-1}$ and decreased available micronutrients.

The Fageria et al., (2008) studied that application of lime influence on common bean changes in soillchemical properties of an Oxisol under no-tillage system. Application of lime significantly affect soil chemical properties in the top $(0-10 \mathrm{~cm})$ as well as in the sub $(10-20 \mathrm{~cm})$ soil layer in favor of higher bean yield (Table 1$)$. The soil $\mathrm{pH}$ and base saturation values were significantly increased with increasing application of lime rate in the top $(0-10 \mathrm{~cm})$ as well as in the sub-soil layer $(10-20 \mathrm{~cm})$. Whereas acidity saturation significantly $(\mathrm{P}<0.01)$ decreased with increasing application of lime rate as expected. Soil $\mathrm{pH}$ and base saturation values were higher in the top $(0-10 \mathrm{~cm})$ soil layer compared with sub-soil layer $(10-20 \mathrm{~cm})$. The acidity saturation and $\mathrm{H}+\mathrm{Al}$ values were significantly decreased with increasing application lime rate and values of these two soil chemicals properties were higher in the sub-soil $(10-20 \mathrm{~cm})$ layer compared with top soil layer $(0-10 \mathrm{~cm})$. The CEC significantly decreased at 12 and $24 \mathrm{Mg}$ lime $\mathrm{ha}^{-1}$ rates compared with control (no lime) treatment. 
Table 1. Selected soil chemical properties after harvest of common bean crops at two soil depths as influenced by liming treatments

\begin{tabular}{|c|c|c|c|c|c|}
\hline \multirow[b]{2}{*}{ Soil property } & \multicolumn{3}{|c|}{ Lime rate $\left(\mathrm{Mg} \mathrm{ha}^{-1}\right)$} & \multirow[b]{2}{*}{ F-Test } & \multirow[b]{2}{*}{$\mathrm{CV} \%$} \\
\hline & 0 & 12 & 24 & & \\
\hline \multicolumn{6}{|c|}{ (0-10 cm depth) } \\
\hline $\mathrm{pH}$ & $5.4 \mathrm{c}$ & $6.7 b$ & $7.1 \mathrm{a}$ & $* *$ & 2 \\
\hline Base saturation $(\%)$ & $27.9 \mathrm{c}$ & $70.5 b$ & $84.3 \mathrm{a}$ & $* *$ & 21 \\
\hline $\mathrm{H}+\mathrm{Al}\left(\mathrm{cmolc} \mathrm{kg}^{-1}\right)$ & $7.0 \mathrm{a}$ & $2.3 b$ & $1.2 \mathrm{c}$ & $* *$ & 19 \\
\hline Acidity Saturation (\%) & $7.2 \mathrm{a}$ & $2.1 b$ & $1.6 \mathrm{c}$ & $* *$ & 25 \\
\hline $\mathrm{Ca}\left(\mathrm{cmolc} \mathrm{kg}^{-1}\right)$ & $1.9 \mathrm{c}$ & $3.9 \mathrm{~b}$ & $4.7 \mathrm{a}$ & $* *$ & 10 \\
\hline $\operatorname{Mg}\left(\right.$ cmolc $\left.\mathrm{kg}^{-1}\right)$ & $0.5 b$ & $1.4 \mathrm{a}$ & $1.4 \mathrm{a}$ & $* *$ & 13 \\
\hline 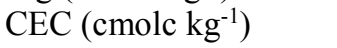 & $9.7 \mathrm{a}$ & $7.9 \mathrm{~b}$ & $7.5 b$ & $* *$ & 8 \\
\hline \multicolumn{6}{|c|}{ (10-20 cm depth) } \\
\hline $\mathrm{pH}$ & $5.3 \mathrm{c}$ & $6.1 b$ & $6.5 \mathrm{a}$ & $* *$ & 2 \\
\hline Base Saturation (\%) & $24.6 \mathrm{c}$ & $49.5 b$ & $62.8 \mathrm{a}$ & $* *$ & 21 \\
\hline $\mathrm{H}+\mathrm{Al}\left(\mathrm{cmolc} \mathrm{kg}^{-1}\right)$ & $7.1 \mathrm{a}$ & $4.4 b$ & $3.1 \mathrm{c}$ & $* *$ & 14 \\
\hline Acidity Saturation (\%) & $7.6 \mathrm{a}$ & $5.2 b$ & $3.7 \mathrm{c}$ & $* *$ & 7 \\
\hline $\mathrm{Ca}\left(\mathrm{cmolc} \mathrm{kg}^{-1}\right)$ & $1.7 \mathrm{c}$ & $2.9 \mathrm{~b}$ & $3.8 \mathrm{a}$ & $* *$ & 15 \\
\hline $\mathrm{Mg}\left({\left.\mathrm{cmolc} \mathrm{kg}^{-1}\right)}^{-1}\right.$ & $0.4 \mathrm{c}$ & $1.1 \mathrm{~b}$ & $1.3 \mathrm{a}$ & $* *$ & 15 \\
\hline  & $9.4 \mathrm{a}$ & $8.7 \mathrm{ab}$ & $8.4 \mathrm{~b}$ & $* *$ & 11 \\
\hline
\end{tabular}

Values are averages of three bean crops at harvest.

**, NS Significant at the $1 \%$ probability level and no significant, respectively. Means followed by the same letter in the same line for the same parameter under different lime treatments are statistically not significant at the $5 \%$ probability level by Tukeys test.

Source: (Fageria et al., 2008)

Kebede and Dereje (2017) showed that application of lime results in reduction of exchangeable acidity $3.55 \pm 0.07$ to $0.93 \mathrm{cmol} \mathrm{Kg}^{-1}, \mathrm{Al}$ saturation $2.86 \pm 0.01$ to $0.027 \mathrm{cmol} / \mathrm{kg}$ and thereby increasing soil $\mathrm{pH}\left(\mathrm{H}_{2} \mathrm{O}\right) 5.3$ to 6.9. Asmare et al. (2015) revealed that the highest lime rate (11.2 ton ha $\left.\mathrm{H}^{-1}\right)$ significantly increased the $\mathrm{pH}$ from 4.89 to 6.03 and reduced the exchangeable acidity from 2.22 to $0.14 \mathrm{cmolc} \mathrm{kg}^{-1}$ and exchangeable $\mathrm{Al}$ from 1.28 to $0.07 \mathrm{cmolc} \mathrm{kg}^{-1}$. The highest lime rates $\left(11.2 \mathrm{t} \mathrm{ha}^{-1}\right)$ also significantly increased Bray I extractable $\mathrm{P}$ by $96 \%$ and the Olsen P by $124 \%$, over the control.

\section{Effect of lime treatment on crops yield}

Application of lime improves the yield of crops if an acidic soil has essential nutrients reduced unavailable to crops due to low $\mathrm{pH}$. However, if the soils are already depleted of nutrients, limited response is expected to application lime only (Marschner, 2011). According to Osundwa et al. (2013), soil acidity problems can be corrected by the use of lime. Applications of lime improved soil conditions resulting in increase in, available P, yield and nutrient uptake ( $\mathrm{N}$ and $\mathrm{P})$. A combination of lime and phosphorus fertilizer resulted in higher grain production than that with lime or P used independently (Kisinyo, 2016).

Sultana et al. (2009) observed that the grain yields of wheat were positively correlated with soil $\mathrm{pH}$, available $\mathrm{P}, \mathrm{Ca}$ and $\mathrm{Mg}$ contents of postharvest soils. Tiller number per plant, grains per spike, grain and straw yields were significantly affected by liming. The application rate of 2.0 ton lime ha ${ }^{-1}$ produced grain yield of $4659 \mathrm{~kg} \mathrm{ha}^{-1}$ which was statistically similar to those treatments in $2.5,3$ and $3.5 \mathrm{t} \mathrm{ha}^{-1}$ lime rates but higher to those in applications of $0,05,1$ and $1.5 \mathrm{tha}^{-1}$ lime rates. Application of lime was increased total uptake of $\mathrm{P}, \mathrm{S}, \mathrm{Ca}$ and $\mathrm{Mg}$ which was mainly associated with increased wheat yields.

Liming is an important practice to achieve optimum yields of all crops grown on acid soils. Shiferaw and Anteneh (2014) have reported increase in barley yield as a result of increased $\mathrm{pH}$ and reduced exchangeable aluminum and in part due to improved nutrients recovery as a result of lime application. Sole application of 3.7 ton lime $\mathrm{ha}^{-1}$ has also been reported to have increased wheat grain yield by twice of the control treatment (no limed) (Guangdi et al., 2009).

The application of lime showed to increase the overall production of various crops. The previous studies done on different crops demonstrated that when 2, 1.5 and $2.2 \mathrm{t} \mathrm{ha}^{-1}$ of lime applied in wheat; there were yield increases of 1767,2020 and $1090 \mathrm{~kg} \mathrm{ha}^{-1}$, respectively. The lime rate of 10,6 and $1.65 \mathrm{t} \mathrm{ha}^{-1}$ applied in the fields of barley; there were yield increases of 361,670 and $2057 \mathrm{~kg} \mathrm{ha}^{-1}$, respectively. The lime rate of 10 and $6 \mathrm{t} \mathrm{ha}^{-1}$ applied in the fields of maize; there were yield increases of 2640, 1400 and $6100 \mathrm{~kg} \mathrm{ha}^{-1}$, respectively. The lime rate of 5.6 and $1 \mathrm{t} \mathrm{ha}{ }^{-1}$ applied in the fields of soybean; there were yield increases of 148 and $481 \mathrm{~kg} \mathrm{ha}^{-1}$, respectively. The lime rate of $4.2 \mathrm{t} \mathrm{ha}^{-1}$ applied in the field of potato the yield increase was $10,000 \mathrm{~kg} \mathrm{ha}^{-1}$. The lime rate of $2 \mathrm{tha}^{-1}$ applied in the field of cabbage and cauliflower the yield increases were $10,000 \mathrm{~kg} \mathrm{ha}^{-1}$ and 5,000 $\mathrm{kg} \mathrm{ha}^{-1}$, respectively (Table 2). 
Table 2. Effects of lime on yield of some main crops

\begin{tabular}{|c|c|c|c|c|c|}
\hline Crops & $\begin{array}{l}\text { Control } \\
\text { Grain Yield } \\
\left(\mathrm{kg} \mathrm{ha}^{-1}\right)\end{array}$ & $\begin{array}{l}\text { Lime treated } \\
\text { grain Yield }(\mathrm{kg} \\
\left.\mathrm{ha}^{-1}\right)\end{array}$ & $\begin{array}{l}\text { Yield } \\
\text { Advantages } \\
(\%)\end{array}$ & $\begin{array}{l}\text { Amount of } \\
\text { Lime } \\
\left(\mathrm{t} \mathrm{ha}^{-1}\right)\end{array}$ & References \\
\hline Wheat & 2895 & 4659 & 61 & 2 & (Sultana et al., 2009) \\
\hline Wheat & 2710 & 4730 & 75 & 1.5 & (Kamaruzzaman et al., 2013) \\
\hline Wheat & 890 & 1980 & 123 & 2.2 & (Mekonnen et at., 2014) \\
\hline Barley & 675 & 1036 & 53 & 10 & (Achalu et al., 2012) \\
\hline Barley & 2270 & 2940 & 30 & 6 & (Tadesse et al., 2018) \\
\hline Barley & 3060 & 5117 & 67 & 1.65 & (Getachew et al. 2017) \\
\hline Maize & 9240 & 11880 & 29 & 10 & (Domagoj et al., 2012) \\
\hline Maize & 2200 & 3600 & 64 & 3.2 & (Mbakaya et al., 2011) \\
\hline Maize & 4100 & 10200 & 249 & 0.725 & (Mihiretu et al., 2014) \\
\hline Potato & 14000 & 24000 & 71 & 4.2 & (Nduwumuremyi et al., 2013) \\
\hline Soybean & 613 & 761 & 24 & 5.6 & (Dessalegn et al., 2018) \\
\hline Soybean & 2013 & 2494 & 25 & 1 & (Maria et al., 2014) \\
\hline cabbage & 56000 & 66000 & 18 & 2 & (Nazrul and Shaheb, 2016) \\
\hline cauliflower & 47000 & 52000 & 11 & 2 & (Nazrul and Shaheb, 2016) \\
\hline Beans & 1030 & 2300 & 123 & 4.42 & (Beernaert, 1999.) \\
\hline
\end{tabular}

Abreha et al. (2013) reported that the applications of combined NP fertilizers along with Wukro and Sheba limes (NP + Wukro lime and NP + Sheba lime) revealed significant increase over control by about 239 and $233 \%$ in grain yield and by 174 and $172 \%$ in biomass yield, respectively. As a result of the application of NP + Wukro lime and NP + Sheba lime, the grain yield obtained by application of only NP rise by about 86 and $90 \%$, respectively. Mekonnen et al. (2014) revealed the combined application of $5 \mathrm{t}$ manure and $2.2 \mathrm{tha}^{-1}$ lime increased grain yield and straw yield by $279 \%$ and $187 \%$, respectively over the control treatment. As Fageria et al. (2008) study indicated that liming is an effective method of increasing common bean yield in Brazilian Oxisols.

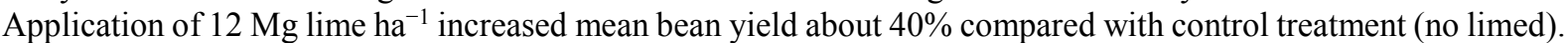
Increases in shoot dry weight and pod number were mainly responsible for yield increase with liming treatments.

According to Temesgen et al. (2014), that studies on the effects of lime on grain yield and yield components of barley combined over two years is presented in Table 2. The highest mean grain yield, biomass yield, plant height and number of tillers were recorded in the lime amended plots. The results showed that the highest significant grain yield and biomass yield were recorded by application of 1.65 and $2.2 \mathrm{t} \mathrm{ha}^{-1}$ lime. Analysis of variance showed that all limed treatments had higher mean values of thousand seed weight, number of seeds per spike and hectoliter weight relative to control (no lime and P) both in 2010 and 2011 cropping seasons. Applications of $1.65 \mathrm{Mg} \mathrm{ha}^{-1}$ of lime gave the maximum grain yield of barley, which was five times the yield obtained by conventional way of barley production (Table 3 ).

Table 3. Number of tillers per square meter, TSW, HLW, grain yield, biomass yield and plant height as affected by lime combined over two years.

\begin{tabular}{clllllll}
\hline $\begin{array}{l}\text { Lime rate L } \\
\left(\mathrm{Mg} \mathrm{ha}^{-1}\right)\end{array}$ & $\begin{array}{l}\text { No.of } \\
\text { tillers/m2 }\end{array}$ & NSPS & TSW & HLW & $\begin{array}{l}\text { Grain yield } \\
\left(\mathrm{kg} \mathrm{ha}^{-1}\right)\end{array}$ & $\begin{array}{l}\text { Biomass yield } \\
\left(\mathrm{kg} \mathrm{ha}^{-1}\right)\end{array}$ & $\begin{array}{l}\text { Plant height } \\
(\mathrm{cm})\end{array}$ \\
\hline 0 & $285.4 \mathrm{~d} \dagger$ & $31.2 \mathrm{~d}$ & $45.2 \mathrm{~b}$ & $65.0 \mathrm{a}$ & $2544.4 \mathrm{~d}$ & $7619.7 \mathrm{~d}$ & $100.2 \mathrm{c}$ \\
0.55 & $303.1 \mathrm{c}$ & $34.6 \mathrm{c}$ & $46.6 \mathrm{a}$ & $65.2 \mathrm{a}$ & $3334.9 \mathrm{c}$ & $9420.3 \mathrm{c}$ & $107.1 \mathrm{~b}$ \\
1.10 & $312.4 \mathrm{bc}$ & $39.7 \mathrm{~b}$ & $47.2 \mathrm{a}$ & $65.2 \mathrm{a}$ & $3796.0 \mathrm{~b}$ & $11005.0 \mathrm{~b}$ & $109.3 \mathrm{ab}$ \\
1.65 & $323.8 \mathrm{ab}$ & $45.1 \mathrm{a}$ & $47.6 \mathrm{a}$ & $65.4 \mathrm{a}$ & $4213.1 \mathrm{a}$ & $11956.7 \mathrm{a}$ & $111.6 \mathrm{a}$ \\
2.20 & $335.0 \mathrm{a}$ & $46.3 \mathrm{a}$ & $47.7 \mathrm{a}$ & $65.5 \mathrm{a}$ & $4297.5 \mathrm{a}$ & $12325.4 \mathrm{a}$ & $111.7 \mathrm{a}$ \\
LSD $(0.05)$ & 16.9 & 2.2 & 1.1 & ns & 200.5 & 770.5 & 2.8 \\
\hline
\end{tabular}

Note: $\mathrm{NSPS}=$ number of seeds per spike; TSW $=$ thousand seed weight; HLW $=$ hectoliter weight; $\dagger$ Mean values within a column that share similar letters are not significantly different at $\mathrm{p}<0.05$; respectively; ns $=$ Not significant

Source: Temesgen et al. (2014).

Getachew et al. (2017) reported that the application of lime and P fertilizer had significantly improved grain yield of barley and soil chemical properties. Barley grain yield increased progressively with higher application of lime and $\mathrm{P}$ rates. The highest yield was 2.2 lime $\mathrm{tha}^{-1}$ and $30 \mathrm{P} \mathrm{kg} \mathrm{ha}^{-1}$ fertilizer applications. Mean barley grain yield increment in the combined analysis at $1.65 \mathrm{t} \mathrm{ha}^{-1}$ lime combined with $20 \mathrm{~kg} \mathrm{ha}^{-1} \mathrm{P}$ application was $183.5 \%$ control.

\section{SUMMARY AND CONCLUSION}

Soil acidity associated to Al toxicities, soil erosion and soil nutrient depletion are the main soil related constraints to agricultural development in parts of developing countries relying on agricultural to feed their growing 
population. The smallholder farmers possess small sizes of land and are resource poor and have difficulties in managing acidic soils. The potentials of using lime for soils sustainable management are among the other options to explore in restoring soil health and fertility. In agriculture, the limes play a great importance in improving soil acidity and hence favor plant nutrition. In addition, lime requirement calculation is of help tool in avoiding under or over liming acidity soils which are detrimental and compromising soil health and plant growth in general. Therefore, there is a need of advocating the use of lime in proper manner and take precaution before liming any acidic soils.

The review articles are support the idea that liming ameliorates soil acidity and improve soil chemical properties making it favorable for the crop growth. Further research would have been required on the same farmer field lime was applied in the next cropping season to observe a significant increase in grain yield. Lime recommendations have to be as specific as possible, taking soils, crops, and climate as well as the financial position of farmers into account. Other alternatives should also be tried. Choice of acid-tolerant crop varieties and use of compost and farm manure may further reduce the amounts of lime required and make farming more attractive. Lime recommendation should be developed for major crop types produced in the area and would be respondent to the change in soil pH, as lime recommendation is crop specific. Socioeconomic (e.g. cost-benefit) analysis would be vital as farmers adoption for lime application to their acidic soils is another challenge and they need to be convinced it will be worth investing in. Lime is a recent agriculture input, in Ethiopian context, which worsen the livelihood of smallholder farmers unless credit service or subsidy is facilitated; which also requires an in-depth research.

\section{REFERENCES}

Abdissa Bekele, Kibebew Kibret, Bobe Bedadi, Markku Yli-Halla and Tesfaye Balemi. 2018. Effects of Lime, Vermicompost, and Chemical P Fertilizer on Selected Properties of Acid Soils of Ebantu District, Western Highlands of Ethiopia. Applied and Environmental Soil Science, 2018, 13

Abreha Kidanemariam, Heluf Gebrekidan, Tekalign Mamo, Kindie Tesfaye. 2013. Wheat crop response to liming materials and NP fertilizers in acidic soils of Tsegede highlands, northern Ethiopia. Agriculture Forestry and Fisheries, 2(3):126-135.

Achalu Chimdi, Heluf Gebrekidan, Kibabew Kibret and Tadesse, A. 2012. Effect of liming on acidity related chemical properties of soils of different land use system in western Oromia, Ethiopia. World Journal of Agricultural Science, 8(6):560-567.

Andy Wijanarko and Abdullah Taufiq. 2016. Effect of Lime Application on Soil Properties and Soybean Yield on Tidal Land. AGRIVITA, 38(1)

Asmare Melese, Markku, Y.H. and Birru Yitaferu, 2015. Effects of Lime, Wood Ash, Manure and Mineral P Fertilizer Rates on Acidity Related Chemical Properties and Growth and P Uptake of Wheat (Triticum aestivum L.) on Acid Soil of Farta District, Northwestern Highlands of Ethiopia. International Journal of Agriculture and Crop Sciences, 8(2) 256-269.

Beernaert FR, 1999. Feasibility study of production of lime and or ground travertine for management of acidic soils in Rwanda. Brussels: Pro-Inter Project Consultants.

Caires, E.F., Barth, G., Garbuio, F.J. and Hurka, S. 2008. Soil acidity liming and soybean performance under notill. Science Agricultural (Piracicaba Braz.) 65(5): 532-540.

Caires, E., Alleoni, L., Cambri M. and Barth, G. 2005. Surface application of lime for crop grain production under a no-till system. American Society of Agronomy J., 97: pp791-798

Chude, V. O., Malgwi, W. B., Amapu, I.Y. and Ano, O.A. 2004. Manual on soil fertilizer assessment. Published by Federal fertilitzer Department in collaboration with National Special Programme for Food Security, AbujaNigeria. Pp. 32:38.

Crawford, T.W., Singh, J.U. and Breman, H. 2008. Solving Agricultural Problems Related to Soil Acidit y in Central Africa's Great Lakes Region

Dessalegn Tamene, Bekele Anbessa and Tigist Adisu. 2017. Influence of Lime and Phosphorus Fertilizer on the Acid Properties of Soils and Soybean (Glycine max L.) Crops Grown in Benshangul-Gumuze Regional State Assosa Area. Advances in Crop Science and Technology, 5:6, 323

Domagoj, R., Zoran, S., Mirta R., Ana G.Residual 2012. Effect of Liming on Soil Properties and Maize Grain Yield. Third International Scientific Symposium "Agrosym Jahorina" 10.7251/AGSY1203087RUDK 631.4+633.15

Fageria NK, Baligar VC, 2008, Ameliorating soil acidity of tropical oxisols by liming for sustainable crop production. In: SPARKS DL, editor, Advances in Agronomy. 99. Brazil: Academic Press, pp. 345 -389.

Getachew Alemu, Temesgen Desalegn, Tolessa Debele, Ayalew Adela, Geremew Taye and Chelot Yirga. 2017. Effect of lime and phosphorus fertilizer on acid soil properties and barley grain yield at Bedi in Western Ethiopia. African Journal of Agriculture Research, 12(40): 3005-3012.

Guangdi, D., P. Rajinder, P. John and R. Keith., 2009. A financial analysis of lime application in a long-term agronomic experiment on the south western slopes of New South Wales. Crop and Pasture Science, 61:12-23. 
Kamaruzzaman, M., Mohammad, R., Nurul, I. 2013. Effect of lime on yield contributing characters of Wheat in Barindtract of Bangladesh. Journal of Agriculture and Veterinary Science: 2319-2372

Kebede Dinkecha and Dereje Tsegaye. 2017. Effects of Liming on Physicochemical Properties and Nutrient Availability of Acidic Soils in Welmera Woreda, Central Highlands of Ethiopia. Biochemistry and Molecular Biology, 2(6): 102-109.

Kim, H. Tan. 2010. Principles of soil environmental chemistry. CRC press, New York.

Kisinyo P. O., 2016. Long term effects of lime and phosphorus application on maize productivity in an acid soil of Uasin Gishu County, Kenya. Sky Journal of Agricultural Research, 5(3):048 - 055

Kisinyo, P. O., Gudu, S. O., Othieno, C. O., Okalebo, J. R., Agalo, J. J., Maghanga, J. K., Opala, P. A., Kisinyo, J. A., Osiyo, R. J., Ngetich, W. K., Makatiani, E. T., Odee, D.W., Cherushama, S. A. and Esegu, J. 2009. Effects of lime, phosphorus and Rhizobia on the growth of Sesbaniasesban in western Kenya acid soils. Emir. J. Food Agric. 21 (2): 164-177

Lofton, J., Godsey, C. B., and Zhang, H. 2010. Determining aluminum tolerance and critical soil pH for winter canola production 15 for acidic soils in temperate regions. Agronomy Journal, 102, 327-332

M Abdulaha-Al Baquy, Jiu-yu Li, Chen-yang Xu, Khalid Mehmood and Ren-kouXu. 2016. Determination of critical $\mathrm{pH}$ and $\mathrm{Al}$ concentration of acidic Ultisols for wheat and canola crops, Solid Earth Discuss., doi:10.5194/se-126, 2016

Meriño-Gergichevich, C., Alberdi, M., Ivanov, A. and Reyes-Díaz, M. 2010. $\mathrm{Al}^{3+-} \mathrm{Ca}^{2+}$ Interaction in plants growing in acid soils: Al-phytotoxicity response to calcareous amendments. J. Soil Sci. Plant Nutr., 10, 217243

Moon, D.H., Chang, Y.Y., Ok, Y.S., Cheong, K.H., Koutsospyros, A. and Park, J.H. 2014 Amelioration of acidic soil using various renewable waste resources. Environ Sci. Poll Res 21: 774-780.

Mbakaya DS, Okalebo JR, Muricho M, Lumasayi S, 2011. Effects of liming and inorganic fertilizers on maize yield in Kakamega north and ugunja districts, Western Kenya. Nairobi, Kenya: KARI.

Mekonnen Asrat, Heluf Gebrekidan, Markku Y.H., Bobe Bedadi, Wakene Negassa. 2014. Effect of Integrated Use of Lime, Manure and Mineral P Fertilizer on Bread Wheat (Triticum Aestivum) Yield, P uptake and Status of Residual Soil P on Acidic Soils of Gozamin District, North-Western Ethiopia. Agriculture, Forestry and Fisheries, 3(2): 76-85.

Nazrul, M. I. and Shaheb, M. R. 2016. Integrated Approach for Liming and Fertilizer Application on Yield of Cabbage and Cauliflower in Acidic Soil of Sylhet. Bangladesh Agronomy Journal, 19(1):49-57

Nduwumuremyi A, Mugwe JN, Ruganzu V, Rusanganwa KC, Nyirinkwaya B, 2013. Effects of Travertine in Improving Selected Soil Properties and Yield of Irish Potato (Solumun tuberosum L.) in Acidic Soils. Journal Agricultural Science Technology A., 3: 175-182.

Nekesa, A. O. 2007. Effect of Minjingu phosphate rock and agricultural lime on maize, groundnut and soybean yields on acid soils of western Kenya. M. Phil Thesis, Moi University, Eldoret, Kenya.pp 45.

Osundwa, M.A., Okalebo, J.R., Ngetich, W.K., Ochuodho, J.O., Othieno, C.O., Langat, B. and Omenyo, V.S. 2013. Influence of Agricultural Lime on Soil Properties and Wheat (Triticum aestivum L.) Yield on Acidic Soils of Uasin Gishu County, Kenya. American Journal of Experimental Agriculture, 3(4): 806-823.

Sadiq, A.A. and U. Babagana. 2012. Influence oflime materials to ameliorate acidity on irrigated paddy fields: A review, Academic Research International. 3(1):17-25.

Schroder, J. L., Zhang, H. L., Girma, K., Raun, W.R., Penn, C. J., and Payton, M. E. 2010. Soil acidification from long-term use of nitrogen fertilizers on winter wheat. Soil Sci. Soc. Am. J., 75, 957-964

Shiferaw Boke and Anteneh Fekadu, 2014. Lime and NPK effect on soil acidity and yield of barley in different acid soils of southern region, Ethiopia. International Journal of Natural Sciences Research, 2(7): 113-122.

Sumner, M.E. and Noble, A.D. 2003. Soil acidification: the world story, In: Rengel, Z., (ed.) Handbook of soil acidity, Marcel Dekker, New York, pp. 1- 28.

Tadesse Moges, Asmare Melese, Girma Tadesse. 2018. Effects of lime and phosphorus fertilizer levels on growth and yield components of malt barley (Hordeum distichum L.) in Angolelana Tera District, North Shewa Zone, Ethiopia. Advances in Plants \& Agriculture Research, 8(6):582-589.

Temesgen D., Getachew, A., Ayalew, A., Tolessa, D., Gonzalo, J., 2014. Effect of lime and phosphorus fertilizer on acid soils and barley (Hordeum vulgare L.) performance in the central highlands of Ethiopia. Accepted in Experimental Agriculture with minor revisions.

Tinker, P. B. and Nye, P. H. 2000. Solute movement in the rhizosphere. Oxford Univ. Press. Oxford, UK.

Waigwa, M.W., Othieno, C.O. and Okalebo, J.R.. 2003. Phosphorus availability as affected by the application of phosphate rock combined with organic materials to acid soils in Western Kenya. Experimental Agriculture, 39, 395- 407.

Wang J., Raman H., Zhang G. Mendham N. and Zou M. 2006. Aluminum tolerance in barely (Horidium vulgarie L.): Physiological mechanisms, genetics and screening methods. Journal of Zhejiang University Science. 7: 769-787. 